\title{
The Effectiveness of Aesthetic Teaching on the Attitude of Elementary School Students
}

DOI: https://doi.org/10.47175/rielsj.v1i3.156

\begin{abstract}
| Ahmad Ahmadi ${ }^{1 *}$ | Roohallah Fathabadi ${ }^{2}$ | Morteza Bakhtiarvand ${ }^{3}$ |
1,3 Ph.D. Candidate in

Educational Technology, Allameh

Tabataba'i University, Tehran,

Iran

2 Ph.D. Student in Psychology of

Exceptional Children, Allameh

Tabataba'i University, Tehran,

Iran

*ahmad.ahmadi7813@gmail.com

ABSTRACT

The aim of this study was to investigate the effect of aesthetics based teaching on students' attitudes toward school. This is an all-experimental study of pre-test-post-test design with a control group. The statistical population of sixth grade students in schools Fardis in the academic year of 1997-98 was. The sampling method was simple random and the selected students were divided into experimental and control groups. The sample size was determined using Morgan table and the number of sample people in each group was 16. Experimental science course was taught in the experimental group by aesthetic teaching method and in the control group by traditional teaching method. To assess the attitude towards school, McCoach (2003) school attitude questionnaire (SAAS-R) was used with a reliability of 0.96. The obtained data were analyzed by multivariate analysis of covariance. The results showed that the level of attitude towards school in students who took the sixth grade experimental sciences course with aesthetic methods was different from the students who learned this course with the usual teaching methods in schools. Therefore, the aesthetic method can play a role as an active and effective method in students' academic achievement in science. KEYWORDS

Aesthetic Teaching; School Attitude; Experimental Sciences
\end{abstract}

\section{INTRODUCTION}

One of the important goals and tasks of education is to create the conditions for the all-round growth of the individual and to train healthy, efficient and responsible human beings to play a role in individual and social life. Since students, as the basic element of the country's educational system, have a special role and position in achieving the goals of the educational system, paying attention to this section of society in terms of education and training, fertility and prosperity of the educational and training system as much as possible Causes. Undoubtedly, one of the goals and tasks of education is to prepare students to accept and understand the scientific developments of the world to come. Nevertheless, its most important goal is the full flourishing of students' personalities and the cultivation of transcendent values (Kadivar, 2011). Meeting this need, which is not easy, requires the expansion of education and the use of methods based on scientific, intellectual, and principled findings to train the specialists needed by society. The future of any society depends on the quality and efficiency of education of that society and the efficiency of the education system of each country depends on recognizing the effective factors in the quality of teaching and using new teaching methods (Abbasi Asl, Saadipour, Asadzadeh, 1395). On the other hand, issues such as academic performance and attitude toward school and the factors affecting those years have been considered by education experts. There are many 
factors that are related to academic performance, including the teaching method and students' attitudes toward school (Samadi, Abedi, Shamsi, Ahmadzadeh, 2015).

Attitude towards school is one of the issues raised in the field of school learning that plays an effective role in students' academic achievement. Attitude towards school is related to the student's way of thinking and interest or disinterest in the school as a whole. (Seif, $1389 \mathrm{p}$. 369). Many who are concerned about educating students believe that one of the most important consequences of educating children is the attitudes they develop toward school. In general, one of the factors influencing the attitude towards school is the role of socioeconomic status, gender, race, ability, academic achievement, self-concept and educational level of students. This is especially true in the early years, as students' attitudes in the first academic year are very flexible (Alan Dean, 2017). Pintrich (2000; quoted by Mousavi and Badri, 2016) believes that attitudes toward school can have a major impact on students' orientation in learning activities. If students feel that their school environment is cold, procrastinating, or contrary to their personal progress, they tend to drop out of school and refuse to attend class (Miller, 2016). Attitudes toward school include the five factors of selfeducation perception, attitudes toward teachers and classes, attitudes toward school, valuing school goals, and self-regulatory motivation.

Self-education perception includes learners' perceptions of their academic abilities and is one of the most important factors influencing their academic achievement. The concept of self-education is a multidimensional structure that requires internal and external comparisons. In this regard, learners compare their performance with their classmates (an external comparison) or compare their performance in one area with their other performance (an external comparison). One of the components of self-education is self-efficacy. Selfefficacy is one of the strongest predictors of academic achievement, course selection, and career decisions at all ages. Self-efficacy refers to the idea that one can be successful in a situation and produce positive outcomes (Santrak, 2002). Students who believe they can be successful in science assignments and activities are more likely to choose such assignments and activities. And they successfully complete these tasks and will resist when faced with problems (Britner, Pajares, 2006).

Another attitude factor related to students' academic achievement is their attitude towards teachers and classes. Teachers 'actions and behavior can affect learners' academic achievement. Many students with low academic achievement have problems with teachers and other school staff. Such students may also be hostile to students. The social atmosphere of the classroom refers to the extent to which the learner feels socially accepted, as well as the extent to which he or she can adapt to and be supported by others (Zeidner \& Schleyer, 2000).

The student's interest and attitude towards school is another factor that includes the student's interest and affection for school. Research shows. The extent to which learners adapt to homework has a lot to do with how they view school. Also, the more positive students are towards school, the higher their academic perception (Leung \& Leung, 1992). McCoach and Siegel (2003) point out that students with poor academic achievement have negative attitudes toward school.

Another factor is the evaluation of school goals; Academic values refer to the extent to which learners are interested in homework, the importance of learning homework, and the potential usefulness of homework for the learner (Wiegfield and Carpetin, 1991). Appreciating learning and believing that the learning task is important improves students' motivation and academic orientation. This component deals with students' arguments for homework. Students 'goals and the value of academic achievement affect their selfregulation and motivation, because students' goals affect the ways in which these goals are 
achieved, as well as the extent to which learners engage and respond to homework (McCoach, Siegel, 2003).

Motivation / self-regulation is the fifth dimension of the attitude towards school. Research findings on motivation / self-regulation indicate that learners, no matter how cognitively and learning strategies are prepared for thematic learning; Again, it is necessary to combine these capabilities and strategies with motivation so that these capabilities and strategies can be useful. Motivated learners do well and are aware of how to cope with learning-related stress. These learners value learning and feel they are good enough to learn (Peter, 2005).

During the 1970s, Brody believed that the educational value of art in schools became apparent when the arts were integrated into the learning process (Zurmpala, 2012). Eisner (2002) and Gardner (2003) took the same position. According to Eisner, the various forms of aesthetic presentation are related to a person's way of experiencing. Gardner, in turn, proposed the theory of multiple intelligences and showed how the arts could be related to ways of thinking. Obviously, this is different from what is promoted in schools. Art is considered as a field through which students will be able to develop their advanced mental abilities. Cognitive development is also related to parameters such as imagination, creativity, intuition and emotions (Park R., 2005). When different arts are presented in the learning process, students and teachers can look at the meanings and messages in different ways and through various contents and try to learn them. In this process, the arts can play a new role and become a center of attention and look at different aspects of knowledge from different angles.

In fact, teaching based on aesthetics is a form of educational activity that seeks to promote students' perception of aesthetics, aesthetic understanding, aesthetic evaluation and aesthetic creativity through a set of activities and good deeds (Linman et al., 2013). ) Which helps to develop worthy individual characteristics and the growth of wisdom. Finally, from the point of view of the effectiveness of teaching, it can be said that this training is a kind of pleasure training. In other words, teaching based on aesthetics is an educational activity that results in students feeling beautiful and pleasant and the teaching process becomes more entertaining (Wang, 2009). Modern education teaches us that every student should have the opportunity to develop the ability to observe, experience, create and evaluate what is beautiful (Denac, 2014).

In the field of aesthetic teaching, little research has been done inside and outside the country. Kiyashñhenko, Plakhova, \& Rakhimova, (2015) examined the components of aesthetics in the formation of vocabulary in the field of art in English language classes. The results of this study showed that aesthetics-based teaching in English language classes using paintings, pictures, stories, elements of popular culture (proverbs, sayings of elders) and its parallel application along with teaching help to develop vocabulary and learn them better, he does. They acknowledged that the results of this study could be used in English language teaching and learning classes; because teaching based on aesthetics improves the performance of learners.

Dyganova \& Karkina (2015) in a study aimed at teaching the aesthetics of music, found that the integration of words with music, as a means of teaching based on an individualistic approach, ensures the success of operations and learning. Innovative art courses by combining words in music as a means of teaching student-centered aesthetics will increase the efficiency of the learning process and will also allow higher education institutions to pursue beauty education as an integrated system. . Inocian (2013) in a study entitled "Transitional Curriculum in Teaching Aesthetics: A Way to Self-Efficacy" using Albert Bandura's theory of self-efficacy in teaching concluded that the use of theory and analysis according to Johnson's philosophical model, Teaching aesthetics and self-efficacy is the 
basis for successful curriculum innovation and leads to growth and excellence in teaching and learning that results in learning success.

Based on research in the field of education, researchers have concluded that the teacher should engage students with what they are learning and teach them how to learn. According to education experts, students who learn through active teaching methods not only learn better, but also enjoy learning more. Because instead of just being listeners, they actively participate in the learning process and consider themselves responsible for their own learning (Jerome, 2011). Therefore, the use of aesthetic teaching methods in the classroom not only makes students more active and motivates them to learn, but also empowers the teacher to transform the classroom environment into a small and pleasant community (Mirasiva, 2010). In general, based on research conducted inside or outside Iran, it can be noted that many factors are effective in students' attitudes toward school that any educational system should be able to identify these factors in order to effectively address the situation. Provide learners for better learning. Therefore, proper planning for optimal platform to improve students' attitudes toward school is a fundamental and key task and requires understanding the current situation and limitations of educational systems.

\section{RESEARCH METHODS}

The present study is a pre-test and post-test design with a control group in terms of data collection. The statistical population of this study included all sixth grade students in schools of Fardis city in the 97-96 academic year. The sampling method of the present study was simple random and the selected students were divided into two groups and one group was randomly considered as the experimental group and the other group as the control group. To determine the sample size, the tables compiled by Morgan using $\alpha=0.05$ were used and the number of samples in the experimental group was 16 and in the control group was 16. It should be noted that the book of experimental sciences was considered for the present study. To conduct the training, for 14 hours during 10 sessions, in the experimental group with the method of teaching aesthetics and in the control group with the method of traditional teaching, the teaching of the sixth science lesson was provided. Before training, pre-test was performed in two groups of control and experimental group, and after the training course, after one week, post-test was performed between the two groups. If the symbols $\mathrm{R}$ are used for random assignment and $\mathrm{O} 1$ and $\mathrm{O} 2$ are used to represent the post-test observation of the two experimental and control groups, respectively, and O' 1 and O'2 are used to represent the pre-test of the experimental and control groups and $\mathrm{x}$, respectively. $\mathrm{x}^{*}$ to show the experimental action intervention (providing training through aesthetic teaching) and $\mathrm{x}$ to show the operation performed in the control group (providing training in the traditional way), this design can be displayed as follows:

\begin{tabular}{|lllll|}
\hline \multicolumn{4}{|c|}{ The Design of Pre-test and Post-test with Control Group } \\
\hline Experimental Group & $\mathrm{O}_{1}$ & $\mathrm{X}^{*}$ & $\mathrm{O}_{1}$ & $\mathrm{R}$ \\
\hline Control Group & $\mathrm{O}_{2}$ & $\mathrm{X}^{*}$ & $\mathrm{O}_{2}$ & $\mathrm{R}$ \\
\hline
\end{tabular}

To measure the attitude towards school, the standard questionnaire for measuring attitude towards school (SAAS-R) McCouch (2003) was used. The initial form of this questionnaire, which included 45 questions, was prepared by McCoach and Siegel (2002) and its purpose was to assess the factors related to students' academic achievement or lack of academic achievement and their attitudes toward school. McCouch and Siegel (2003) prepared 43 questions in the SAAS-R revision form after various reviews and performed various analyzes on the reliability and validity of this questionnaire. This questionnaire was standardized by Mesr Abadi (2010) and its construct validity was determined by has been 
investigated and validated through heuristic factor analysis. It should be noted that the attitude towards school questionnaire has 5 subscales of attitude towards teacher and class $(1,7,11,12,13,25,28)$, motivation / self-regulation $(6,8,18,20,2426,27,29,30)$, attitude towards school $(4,5,9,15,35)$, self-educational perception $(2,3,16,31,33,34)$ and evaluation of goals $(17,19,22,23,32)$. The reliability of this questionnaire in Mesr Abadi (2010) research was equal to 0.91 in Cronbach's alpha coefficient. In the present study, the overall reliability of the instrument was obtained using Cronbach's alpha coefficient $\alpha=0.96$. Finally, the collected data were analyzed using spss.vs.22 software using analysis of covariance (MANCOVA). It should be noted that in order to comply with ethical considerations, measures were taken, including obtaining the consent of the participants to participate in the research, keeping the names of individuals confidential and the availability of the researcher to answer questions.

\section{RESULTS AND DISCUSSION}

Data analysis was performed in two ways: descriptive and inferential. In the descriptive part of the descriptive tables, which included the mean and standard deviation; used. Table (1) shows this data.

Table 1. Mean and standard deviation of attitudes toward school in two stages of measurement by experimental and control groups

\begin{tabular}{|c|c|c|c|c|c|}
\hline \multirow{2}{*}{$\begin{array}{l}\text { Post-test } \\
\text { The } \\
\text { standard } \\
\text { deviation }\end{array}$} & \multicolumn{3}{|c|}{ Pre-test } & \multirow[b]{2}{*}{ Variable } & \multirow[b]{2}{*}{ Group } \\
\hline & Average & $\begin{array}{l}\text { The } \\
\text { standard } \\
\text { deviation }\end{array}$ & Average & & \\
\hline 2.086 & 21.07 & 1.870 & 19.93 & $\begin{array}{l}\text { Attitudes towards the } \\
\text { teacher and the class }\end{array}$ & control \\
\hline 1.922 & 25.87 & 2.031 & 25.13 & Motivation / self-regulation & \\
\hline 1.298 & 18.40 & 1.633 & 17.67 & Attitude towards school & \\
\hline 1.543 & 20.33 & 1.549 & 19.40 & Self-educational perception & \\
\hline 0.986 & 19.21 & 1.113 & 18.33 & Valuing goals & \\
\hline 2.242 & 22.80 & 2.520 & 20.73 & $\begin{array}{l}\text { Attitudes towards the } \\
\text { teacher and the class }\end{array}$ & experiment \\
\hline 1.885 & 26.47 & 1.952 & 24.67 & Motivation / self-regulation & \\
\hline 0.961 & 19.07 & 1.397 & 17.33 & Attitude towards school & \\
\hline 1.805 & 21.40 & 1.995 & 19.47 & Self-educational perception & \\
\hline 1.859 & 20.80 & 1.302 & 18.53 & Valuing goals & \\
\hline
\end{tabular}

Table 1 shows the descriptive statistics related to the mean and standard deviation of attitudes toward school separately for experimental and control group students in two stages of assessment (pre-test and post-test). As can be seen, in the control group, the mean scores in the pre-test and post-test stages do not show much change, but in the experimental group, we see a greater increase in scores in the post-test than in the pre-test.

In order to evaluate the effectiveness of aesthetic teaching on attitudes toward elementary school students, multivariate analysis of covariance (MANCOVA) test was used. Prior to this test, the statistical assumptions of the normality of the distribution of scores using the Kolmogorov-Smirnov test, the homogeneity of the covariance matrix using the Mbox test and the homogeneity of the variances were examined using the Levin test. One of the above assumptions are that the use of multivariate analysis of covariance is unobstructed. 
Table 2. Results of multivariate analysis of covariance to compare attitudes toward school children in the experimental and control groups

\begin{tabular}{ccccccll}
\hline $\begin{array}{c}\text { Effect } \\
\text { size }\end{array}$ & $\begin{array}{c}\text { Significance } \\
\text { level }\end{array}$ & $\begin{array}{c}\text { Degree of } \\
\text { error } \\
\text { freedom }\end{array}$ & $\begin{array}{c}\text { Degree of } \\
\text { freedom of } \\
\text { effect }\end{array}$ & F & Amounts & Exams & Effect \\
\hline 0.651 & 0.001 & 19 & 5 & 7.076 & 0.651 & Pillay effect & \\
0.651 & 0.001 & 19 & 5 & 7.076 & 0.349 & Wilks Lambda & \\
0.651 & 0.001 & 19 & 5 & 7.076 & 1.862 & Hoteling effect & group \\
0.651 & 0.001 & 19 & 5 & 7.076 & 1.862 & $\begin{array}{l}\text { The biggest } \\
\text { root on }\end{array}$ \\
\hline
\end{tabular}

As can be seen, the significance level of all four relevant multivariate statistics, namely Pillay effect, Wilkes lambda, hoteling effect and the largest zinc root, is less than 0.01 ( $p$ $<0.01$ ). Thus, the statistically zero hypothesis is rejected and it is determined that there is a significant difference between the attitudes toward school between the experimental and control groups in the post-test. Based on this, it can be said that aesthetic teaching has been effective on attitudes toward elementary school students. In order to investigate the differences between the experimental and control groups in each of the subscales of attitude toward school, the inter-subject effects test was used and the results are presented below.

Table 3. Inter-subject effects test to compare the subscales of attitude toward school in the experimental and control groups in the post-test

\begin{tabular}{cccccccl}
\hline $\begin{array}{c}\text { Effect } \\
\text { size }\end{array}$ & $\begin{array}{c}\text { Signifi- } \\
\text { cance } \\
\text { level }\end{array}$ & F & $\begin{array}{c}\text { Average } \\
\text { squares }\end{array}$ & $\begin{array}{c}\text { Degrees } \\
\text { of } \\
\text { freedom }\end{array}$ & $\begin{array}{c}\text { Total } \\
\text { squares }\end{array}$ & Source & Variable \\
\hline 0.236 & 0.014 & 7.094 & 6.760 & 1 & 6.760 & Intergroup & Attitudes towards the \\
& & & 0.953 & 23 & 21.918 & Intragroup & teacher and the class \\
\hline 0.241 & 0.013 & 7.323 & 8.708 & 1 & 8.708 & Intergroup & Motivation / self- \\
& & 1.189 & 23 & 27.351 & Intragroup & regulation \\
\hline 0.172 & 0.039 & 4.779 & 3.774 & 1 & 3.774 & Intergroup & Attitude towards school \\
\hline 0.190 & 0.029 & 5.407 & 6.106 & 1 & 6.106 & Intergroup & Self-educational \\
& & & 1.129 & 23 & 25.972 & Intragroup & perception \\
\hline 0.215 & 0.020 & 6.284 & 8.858 & 1 & 8.858 & Intergroup & Valuing goals \\
\hline
\end{tabular}

Table 3 shows the test results of inter-subject effects to compare attitudes toward school in the experimental and control groups in the post-test phase. According to the presented results, the value of $\mathrm{F}$ is significant for all subscales at the level of $0.05(\mathrm{P}<0.05)$. Therefore, the null hypothesis is rejected and the research hypothesis is confirmed. Due to the higher mean scores of the experimental group in the post-test stage, it is concluded that aesthetic teaching is effective and improves the attitude towards school in elementary students.

\section{CONCLUSION}

Aesthetic teaching, which manifests itself in art and other subjects, increases the curiosity about beauty in nature and in humans. This sense of beauty is reflected in relevant activities and discussions centered on the subject of beauty, especially in art and creative work (Senemogl \& Gency, 2001). Art is one of the variables that has been shown to have the greatest effect on beauty in awakening (Schirmacher, 1986). In the present study, the relationship between aesthetic teaching and attitude towards school was investigated. The results showed that the effect of aesthetic education and teaching on school attitude was significant. This finding is consistent with the results of many studies, some of which are 
mentioned below. The results of the study showed that teaching aesthetics in English language classes using paintings, pictures, stories, elements of popular culture (proverbs, sayings of elders) and its parallel application along with teaching helps to develop vocabulary and learn them better. They acknowledged that the results of this study could be used in English language teaching and learning classes; because teaching based on aesthetics improves the performance of learners. Dyganova \& Karkina (2015) in a study aimed at teaching the aesthetics of music, found that the integration of words with music, as a means of teaching based on an individualistic approach, ensures the success of operations and learning. Innovative art courses by combining words in music as a means of teaching student-centered aesthetics will increase the efficiency of the learning process and will also allow higher education institutions to pursue beauty education as an integrated system.

Explaining this finding, it can be said that the combination of different arts in the teaching process based on aesthetics leads to meaningful learning. As Flower and Joyce concluded in their research, there is a positive correlation between art-based education and academic achievement. Because aesthetic-based teaching emphasizes students' use of multisensory perception, the learning process takes place through all the senses. Through the use of this method, the curriculum is better understood, which can affect students' attitudes toward school and its variables. This is what Green points out that we need to have a particular conception of aesthetic education. He points out that there should be an emphasis on freeing students to meditate on works of art. The key concept in this case is qualitative understanding. On the other hand, teaching method based on aesthetics is one of the active teaching methods which consists of three methods of using rhythm and music in teaching, using shape, color and images in teaching and using the role-playing method in teaching. Music and rhythm have also influenced the change of students' attitudes, engaging in music stimulates the imagination and innovation of learners and causes active conflict and mental effort of students. What is important here is a conscious approach and participation in this process. As Herbert Marcuse states: "A conscious approach to music and rhythm, and art in general, is always a new beginning; Because it reveals new possibilities of seeing, hearing and feeling; In other words, conscious participation enables learners to better understand poems, images, music, and rhythm in the learning process. Also, their imaginations in these fields should be deeper, more diverse and more extensive. "In order to explain this finding more accurately, it can be said that combining the principles of aesthetics with teaching and applying art and education together, improves guidance and Students learn so that students enjoy this type of learning and consequently have a positive attitude towards the classroom and the teacher and in general a positive attitude towards school. In short, it can be said that serious attention to aesthetic teaching makes educational experiences enjoyable and, as a result, students show more enthusiasm and desire to learn the lessons; By engaging in teaching and being active in learning with enjoyable artistic methods, they do not get tired and try hopefully, and by achieving positive results and progress in learning, they find a positive attitude towards school. It seems that the best and most effective way to teach concepts and sciences is the indirect teaching method.

In this way, the use of art and aesthetic activities has an important and fundamental role. The first and most important stage of education is the elementary school, in which children with different abilities and talents are ready to receive general and basic education. In the meantime, the aesthetic methods of teaching and applying art with its various branches can be very useful and effective in facilitating and accelerating learning and consequently a positive attitude towards school. For this reason, according to the research results, strengthening the sense of responsibility of teachers in using the aesthetic teaching method and promoting the spirit of cooperation and collaboration among teachers to exchange 
experience in using the aesthetic teaching method and applying this method in the classroom. Lesson; It is suggested. In general, a keen awareness of the inherent beauty of scientific ideas and the discoveries of scientists draws people to these sciences. It is necessary to explain how the impact of aesthetic education on students 'attitudes in students' attitudes toward school. In explaining this issue, it is possible to motivate the attraction towards beauty and thus find beauty in the ideas of science and mathematics, and as a result, to find a positive attitude and try to achieve beauty through study and study, and this is it. Affects students' attitudes toward school.

\section{REFERENCES}

Asadian, Azizi, \& Qader. (2018). Aesthetics-Based Teaching: An Approach to Improving Students' Attitudes Towards School. Educational Innovations, 17 (2), 73-96.

Bahraini, Naeema, Mirzabeigi, Sotoudeh, \& Hajar. (2018). Comparison of user behavior and browsing strategies with verbal-two-way-visual cognitive styles in web interaction. Journal of National Library and Information Studies, 28 (4), 129-145.

Pour Hosseini, Sajjadi, Seyed Mehdi, \& Imani. (2015). Explain the implications of John Dewey's view of art and aesthetics for the teaching and learning process. Journal of Research in School and Virtual Learning, 2 (7), 83-100.

Sharifzadeh, Hakimeh Sadat, Baezzat, \& Jalalian Rad. (2016). The effect of teaching method based on aesthetics on the academic achievement of science in fifth grade elementary students. New Educational Thoughts, 12 (3), 183-200.

Mousavi, Frank, Badri, \& Imran. (2016). the relationship between metacognitive awareness and academic self-concept, school attitudes and students' social adjustment. Journal of New Approach in Educational Management, 7 (25), 177-190.

Attar Khamenei, F., \& Seif, A. I. (2009). The effect of teaching metacognitive study learning strategies on students' motivation and academic achievement. Journal of Educational Psychology Studies, 6 (9), 57-74.

Yousefi, \& Mesr Abadi. (2019). Relationship between goal orientation and academic achievement: a meta-analytic study. Journal of Educational Psychology, 15 (51), 71-94.

Khojasteh Mehr, Abbaspour, Zabihollah, Karaei, Amin, \& Kouchaki. (2012). the effect of academic success program on academic performance and self-concept, attitude towards school, learning how to succeed in school and social adjustment of students. School Psychology, 1 (1), 27-45.

Abbasi Asl, R; Saadipour, I; Asadzadeh, H. (2015). Comparison of the Effectiveness of Three Methods of Participatory Learning on Social Skills of Secondary School Students. Quarterly Journal of Educational Innovations, 11 (1): 105-124. (In prison).

Britner, S.L., \& Pajares, F., (2006). Sources of science self-Efficacy beliefs of middle school students. Journal of Research in Science Teaching, 43(5), 485-499.

Busatoa, V.V., Prinsb, F.J., Elshouta, J.J., \& Hamakera, C., (2000). Intellectual ability, learning style, personality, achievement motivation and academic success of psychology students in higher education. Personality and Individual Differences, 29, 1057-1068.

Denac, O. (2014). The significance and role of aesthetic education in schooling. Creative Education, 5(19), 1714.

Dyganova, E. A., \& Karkina, S. V. (2015). Person Oriented Aesthetic Education In The System Of Life-Long Music Education. Procedia-Social and Behavioral Sciences, 191, 1750-1753.

Efland, A. (2002). Art and cognition: Integrating the visual arts in the curriculum. Teachers College Press. 
Flavell, J. H., \& Flavell, E. R. (2004). Development of children's intuitions about thoughtaction relations. Journal of cognition and development, 5(4), 451-460.

Gardner, H. (2003). Multiple intelligences after twenty years Paper presented at the American Educational Research Association. Chicago, Illinois.

Inocian, R. B. (2013). Transitional curriculum in aesthetic teaching: a test for self-efficacy. European Scientific Journal, 9(31).

Kadivar, P. (2011). Educational Psychology, Thirteenth Edition, Tehran: Samt. (In prison).

Kiyashñhenko, Î. A., Plakhova, E. A., \& Rakhimova, M. A. (2015). Aesthetic Component in the Formation of Lexical Area" Art" in English Language Classes. Journal of Sustainable Development, 8(5), 191.

Leung, J. P., \& Leung, K. (1992). Life satisfaction, self-concept, and relationship with parents in adolescence. Journal of Youth and adolescence, 21(6), 653-665.

McCoach, D.B., \& Siegle, D., (2003). The school attitude assessment survey revised: A new instrument to identify academically able students who underachieve. Educational and Psychological Measurement, 63(3), 414-429.

Miller, D. G. (2016). The Impact of Formal Extracurricular Activities on Satisfaction and Attitudes-toward-School among At-Risk Adolescents.

Mirascieva, S. (2010). The integrated access in the preparation and planning of the teaching process at the primary schools in republic of Macedonia. Procedia-Social and Behavioral Sciences, 2(2), 5059-5065.

Parker, J. (2005). A consideration of the relationship between creativity and approaches to learning in art and design. International Journal of Art \& Design Education, 24(2), 186198.

Peter, C., (2005). Learning-who responsibility is it? Nurse Educator, 30, 159-165.

Pour Hosseini, M, Sajjadi, M, \& Amani. H. (2014). Explaining the implications of John Dewey's view of art and aesthetics for the teaching and learning process. Journal of Academic and Vocational Admission Studies, 2 (7): 23-41. (In prison).

Schirmacher R. Talking with young children about their art. Young Children. 1986 Jul 1; 41(5):3-7.

Sotiropoulou, Zurmpala M. (2012) Aesthetic teaching: Seeking a balance between teaching arts and teaching through the arts. Arts Education Policy Review. 2012 Oct 1; 113(4):123-8.

Walker, E., Tabone, C., \& Weltsek, G. (2011). When achievement data meet drama and arts integration. Language Arts, 88(5), 365.

Wang, L., \& Kokotsaki, D. (2018). Primary school teachers' conceptions of creativity in teaching English as a foreign language (EFL) in China. Thinking skills and creativity, 29, 115-130.

Zeidner, M., \& Schleyer, E.J. (1999). Evaluating the effects of full-time vs part time educational programs for the gifted: Affective outcomes and policy considerations. Evaluation and Program Planning, 22, 413-42.

Samadi, M, Abedi, A, Shamsi, A, Ahmadzadeh, M. (2015). Evaluating the Effectiveness of Psychological and Educational Interventions on Improving Academic Performance of Dyslexic Students. Journal of Psychology. 19 (3): 270-285. (In prison).

Geschwind, N., Peters, F., Huber's, M., van Os, J., \& Wichers, M. (2012). Efficacy of mindfulness-based cognitive therapy in relation to prior history of depression: randomized controlled trial. The British Journal of Psychiatry, 201(4), 320-325. 